\title{
WISATA DESA BERBASIS LAHAN RAWA DI DESA HAMBUKU TENGAH
}

\author{
Yuzhirna Najmi Hasanah \\ Program Studi Teknik Arsitektur Fakultas Teknik Universitas Lambung Mangkurat \\ yuzhirnanaj@gmail.com
}

\section{Pakhri Anhar}

Program Studi Teknik Arsitektur Fakultas Teknik Universitas Lambung Mangkurat pakhrianhar@ulm.ac.id

\begin{abstract}
ABSTRAK
Wisata Desa Berbasis Lahan Rawa di Desa Hambuku Tengah adalah tempat rekreasi yang menyuguhkan atraksi berupa adat dan keseharian masyarakat Desa Hambuku Tengah pada masa lampau dan menjadi wadah edukasi terhadap lahan rawa sebagai potensi alam terbesar yang ada di Desa Hambuku Tengah. Wisata ini bertujuan menjadi objek wisata lahan rawa yang dapat mengembangkan potensi desa sehingga mampu meningkatkan perekonomian masyarakat Desa Hambuku Tengah. Pengembangan potensi desa sebagai objek wisata memerlukan analisis terhadap potensi yang dapat dimanfaatkan, melalui metode analisis- sintesis dan konsep memori diharapkan dapat menggali potensi desa yang ada sehingga menciptakan wadah rekreasi dan edukasi lahan rawa sekaligus memberikan kesan dan pengalaman hidup di desa.
\end{abstract}

Kata Kunci : Wisata Desa, Lahan Rawa, Memori

\section{ABSTRACT}

Swamp Based Village Tourism in Central Hambuku Village is a recreation area that presents attractions in the form of customs and daily life of the people of Central Hambuku Village in the past and is a place of education for swamps as the largest natural potential in the Village of Central Hambuku. This tour aims to become a swampy tourist attraction that can develop the potential of the village to improve the economy of the Central Hambuku Village community. The development of village potential as a tourist attraction requires an analysis of the potential that can be exploited, through analysis-synthesis methods and the concept of memory is expected to explore the potential of existing villages to create a place for recreation and education of swamps as well as to give the impression and experience of life in the village.

Keyword : Village Tourism, Swamp Area, memory

\section{PENDAHULUAN}

Wisata merupakan objek rekreasi yang memegang peranan penting dalam industri pariwisata. Objek wisata di Indonesia memiliki beragam daya tarik, terutama dalam hal keunikkan alam, adat dan budaya. Daya tarik yang beragam inilah yang menyebabkan peningkatan wisatawan setiap tahunnya. Peningkatan wisatawan ini akan berdampak terhadap meningkatnya perekonomian, mengingat bahwa peningkatan ekonomi masyarakat tidak terlepas dari peran wisata sebagai bagian utama dari sektor pariwisata. Sektor pariwisata telah menjadi salah satu sektor utama yang mendukung pembangunan Indonesia melalui devisa yang dihasilkan 
sejak tahun 1990. Peningkatan perekonomian masyarakat menurut UNWTO (UN-World Tourism Organization), sejalan dengan peningkatan wisatawan tiap tahunnya. Data menunjukkan bahwa rata-rata kunjungan wisatawan mancanegara pada periode 1994-2002 mengalami peningkatan sebesar 3 persen, dan pada tahun 2004-2012 mengalami peningkatan $13,7 \%$. Peningkatan kunjungan wisatawan mancanegara yang paling signifikan menurut UNWTO (UN-World Tourism Organization) terjadi pada tahun 2017, dengan kunjungan wisatawan mancanegara ke Indonesia tercatat sebanyak 14,04 juta kunjungan. Kunjungan wisatawan mancanegara ke Indonesia pada tahun 2017 naik sebesar 16,77 persen dibandingkan tahun sebelumnya. Data lain yang ditunjukkan oleh Badan Pusat Statistik (BPS) pada tanggal 3 Februari 2020 menunjukkan bahwa terdapat 16,1 juta kunjungan wisatawan mancanegara ke Indonesia pada tahun 2019 dan jumlah kunjungan ini mengalami kenaikan sebesar 1,9 persen dari tahun sebelumnya (Thira, Mayangky, Kholifah, Balla, \& Gata, 2019)

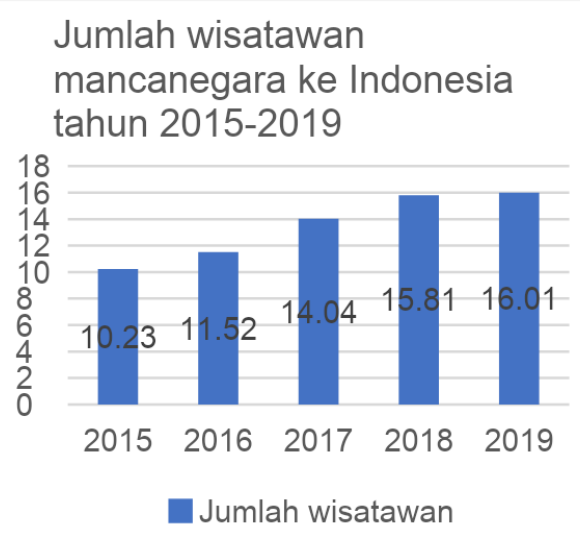

Gambar. 1 Jumlah kunjungan wisatawan mancanegara ke Indonesia

Sumber : (Badan Pusat Statistik Indonesia, 2020)

Peningkatan kunjungan wisatawan mancanegara ke Indonesia tiap tahun juga diikuti dengan peningkatan kunjungan wisatawan nusantara antarprovinsi. Data yang dikeluarkan oleh BPS menunjukkan bahwa terjadi peningkatan kunjungan wisatawan nusantara antar provinsi sebanyak 15,4 persen dari tahun 2015-2018.

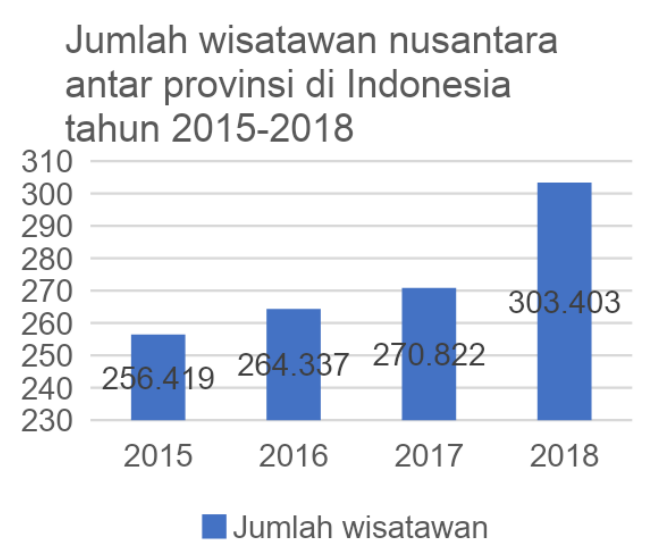

Gambar. 2 Jumlah kunjungan wisatawan nusantara di Indonesia

Sumber : (Badan Pusat Statistik Indonesia, 2020)

Kenaikkan angka kunjungan wisatawan mancanegara dan wisatawan nusantara antar provinsi mendorong pemerintah pusat untuk merancang suatu kebijakan pengembangan pariwisata di Indonesia dengan membangun fasilitas yang lebih baik di objek wisata yang ada. Pemerintah pusat juga menghimbau pemerintah daerah untuk mengembangkan wisata yang ada di daerahnya, serta menggali potensi masing-masing daerah guna menciptakan objek wisata yang baru.

Berkaitan dengan kebijakan yang dikeluarkan oleh pemerintah pusat, Kalimantan Selatan sebagai salah satu provinsi di Indonesia mulai mengalihkan sumber pendapatan daerah (PAD) utama dari sektor pertambangan ke sektor pariwisata. Dikutip dari arah destinasi.com, Wakil Gubernur (Wagub) Provinsi Kalimantan Selatan, Rudy Resnawan menyatakan bahwa Pariwisata telah kami ditempatkan sebagai program prioritas Provinsi Kalsel 2016-2021. Kalsel bertekad ingin mengalihkan sumber ekonomi dari pertambangan ke pariwisata. Tekad pemerintah Provinsi Kalimantan Selatan 
untuk mengembangan pariwisata melalui pengalihan sumber pendapatan daerah (PAD) menunjukkan bahwa Provinsi Kalimantan Selatan ikut serta dalam pengembangan pariwisata sebagai upaya untuk meningkatkan perekonomian masyarakat daerah.

Pengembangan pariwisata sejalan dengan usulan pemerintah Kabupaten Hulu Sungai Utara dan BAPPELITBANG (Badan Perencanaan, Pembangunan, penelitian, dan Pengembangan) mengenai RIPPDA (Rencana Induk Pengembangan Pariwisata Daerah) yang menunjukan bahwa selain sektor rekreasi, pariwisata juga dapat menjadi sarana edukasi yang baik bagi masyarakat daerahnya sendiri maupun masyarakat luar. Pengembangan pariwisata juga akan berdampak pada sektor perekonomian di daerah tersebut. Wisata yang berkembang di suatu daerah akan menyebabkan perekonomian masyarakat di daerah tersebut mengalami peningkatan. Pernyataan ini diperkuat oleh (Alim Irhamna, 2018)yang menyatakan bahwa persentase pendapatan masyarakat mengalami peningkatan yang semula sebesar $53,3 \%$ menjadi $68,5 \%$. Peningkatan pariwisata sangat penting untuk dilakukan di Kabupaten HSU mengingat sedikitnya jumlah objek wisata di pusat Kabupaten. Padahal terdapat beberapa desa yang berpotensi sebagai objek wisata, salah satunya desa Hambuku Tengah yang memiliki potensi untuk dikembangkan menjadi objek wisata baru di daerah tersebut.

Desa Hambuku Tengah berlokasi di Kecamatan Sungai Pandan Kabupaten Hulu Sungai Utara, Provinsi Kalimantan Selatan, Indonesia. Desa Hambuku Tengah memiliki potensi yang dapat dikembangkan dalam sektor alam dan masyarakatnya. Sektor alam yang ada di Desa Hambuku Tengah menjadikan daerah tersebut berpotensi di bidang pertanian, perikanan, dan peternakan, sedangkan sektor masyarakatnya memiliki adat dan kebiasaan yang unik dalam melakukan aktivitas sehari-hari dan bekerja. Selanjutnya dalam bidang pertanian, Desa Hambuku Tengah memproduksi sayur dan buah berupa padi, cabe, terong, singkong, gambas, timun suri, dan lain-lain, sebagai kebutuhan masyarakatnya sendiri. Desa Hambuku juga memiliki lahan rawa yang tergenang pada musim penghujan, telaga, dan sungai yang dapat digunakan sebagai area pemancingan umum. Selain itu, Desa Hambuku Tengah memiliki peternakan itik yang digunakan untuk menunjang kebutuhan masyarakatnya (sumber: hasil wawancara masyarakat Desa Hambuku Tengah dilakukan pada tanggal 20 Juni 2019)

Desa Hambuku Tengah memiliki luas wilayah $1,25 \mathrm{~km}$ dengan sebagian besar lahannya merupakan lahan rawa lebak. Lahan rawa merupakan potensi alam terbesar yang dimiliki oleh desa ini sehingga potensi ini dapat dimanfaatkan oleh Desa Hambuku Tengah sebagai wisata berbasis lahan rawa. Pemanfaatan lahan rawa yang sebagian besar digunakan untuk pertanian dengan total luas $800.000 \mathrm{~m} 2$ yang dimiliki oleh 102 orang menjadikan sebagian besar masyarakatnya memiliki mata pencaharian sebagai petani. Meskipun sebagian besar masyarakatnya berprofesi sebagai petani, masyarakat dari Desa Hambuku Tengah memiliki tingkat pendidikan yang bagus. Hanya terdapat 15 orang yang tidak pernah bersekolah atau memperoleh pendidikan formal dari 539 orang masyarakat Desa Hambuku Tengah. Tingkat pendidikan yang relatif bagus ini menyebabkan masyarakat Desa Hambuku Tengah lebih terbuka terhadap orang luar. Selain itu, tingkat pendidikan yang tinggi dari masyarakat juga memberikan kesempatan yang besar bagi masyarakat untuk dapat menjadi pengelola wisata dan ikut serta mengembangkan wisata tersebut. (sumber : hasil survey lapangan pada tanggal 20 Juni 2019)

Potensi lain yang dapat digali dari Desa Hambuku Tengah adalah keunikan aktivitas bertani dan mencari ikan yang dilakukan masyarakatnya pada masa lampau. Keunikkan ini dapat menjadi daya tarik tersendiri untuk ditampilkan sebagai atraksi wisata. Lebih dari 100 orang masih 
bisa melakukannya dan beberapa di antaranya masih melakukannya sampai sekarang.

Berdasarkan penuturan di atas, kekayaan budaya pada desa yang memiliki karakter khusus berpotensi untuk dijadikan sebagai objek wisata berbasis kearifan lokal seperti tradisi, makanan khas, sistem pertanian, dan karakter sistem sosial yang kuat (Zakaria \& Suprihardjo, 2014) Sejalan dengan itu, ada tahun 2020 UNWTO merayakan tahun pariwisata dan pembangunan pedesaan, dengan harapan bahwa sektor pariwisata dapat memimpin perubahan positif di masyarakat sehingga dapat meningkatkan perekonomian dan melestarikan budaya. Oleh sebab itu, penelitian ini mencoba merancang wisata desa berbasis lahan rawa dengan mengandalkan potensi Desa Hambuku Tengah dan daya tarik masa lampaunya.

\section{PERMASALAHAN}

Berdasarkan latar belakang, tujuan perancangan wisata desa berbasis lahan rawa adalah sebagai wadah rekreasi dan edukasi baru untuk wisatawan dengan mengembangkan potensi Desa Hambuku Tengah sehingga dapat meningkatkan perekonomian masyarakat desa.

Berdasarkan tujuan dan latar belakang, maka muncullah permasalahan arsitektur yaitu, Bagaimana Rancangan wisata desa berbasis lahan rawa dengan mengandalkan daya tarik masa lampu dan potensi Desa Hambuku Tengah ?

\section{TINJAUAN PUSTAKA}

\section{A. Tinjauan Wisata}

1. Pengertian Wisata

Wisata secara umum dapat diartikan sebagai sarana rekreasi. Wisata dapat didefinisikan sebagai suatu perjalanan, namun tidak semua perjalanan dapat dikatakan wisata (Suyitno, 2001). Menurut (Fandeli, 2001) wisata adalah perjalanan atau sebagai bagian dari kegiatan yang dilakukan secara sukarela dan bersifat sementara dalam rangka menikmati objek dan daya tarik wisata tersebut. Wisata memiliki beberapa karakteristik, yang menurut (Suyitno, 2001) meliputi:

a. Bersifat sementara, yang berarti bahwa dalam jangka waktu pendek pelaku wisata akan kembali ke tempat asalnya.

b. Melibatkan komponen - komponen wisata, misalnya sarana transportasi, akomodasi, restoran, objek wisata, toko cinderamata dan lain-lain.

c.Umumnya dilakukan dengan mengunjungi objek wisata dan atraksi wisata.

d. Memiliki tujuan tertentu yang intinya untuk mendapatkan kesenangan.

e. Tidak untuk mencari nafkah di tempat tujuan dan keberadaannya dapat memberikan kontribusi pendapatan bagi masyarakat atau daerah yang dikunjungi.

\section{Syarat Objek Wisata yang dapat} Dikembangkan

Suatu objek wisata dapat
dikembangkan,
apabila syarat-syarat sebagai berikut yaitu (Djauzi, 1997) :

a. Attraction adalah segala sesuatu yang menjadi ciri khas atau keunikan dan menjadi daya tarik wisatawan agar mau datang berkunjung ke tempat wisata. Attraction wisata terdiri dari dua, yaitu:

1) Site Attraction, yaitu daya tarik yang dimiliki oleh objek wisata semenjak objek itu ada. 2) Event Attraction, yaitu daya tarik yang dimiliki oleh suatu objek wisata setelah dibuat manusia.

b. Accessibility, yaitu kemudahan cara untuk mencapai tempat wisata tersebut.

c. Amenity, yaitu fasilitas yang tersedia di daerah objek wisata seperti akomodasi dan restoran.

d. Institution, yaitu lembaga atau organisasi yang mengelola objek wisata tersebut. 


\section{B. Tinjauan Desa Hambuku Tengah}

Berdasarkan data yang diperoleh dari (BPS HSU, 2018) Desa Hambuku Tengah terletak di Kecamatan Sungai Pandan Kabupaten Hulu Sungai Utara Provinsi Kalimantan Selatan, Indonesia dengan koordinat lintang 02029'46, 61'LS dan koordinat bujur 115010'37, 77"BT. Desa Hambuku Tengah merupakan salah satu desa dari 50 desa yang berada di wilayah Kecamatan Sungai Pandan.

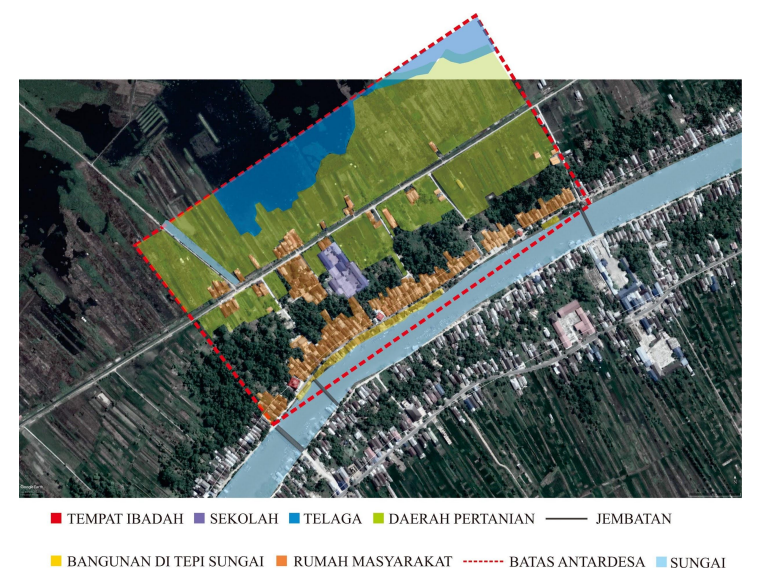

Gambar. 3 Eksisting Desa Hambuku Tengah Sumber : Analisis Pribadi (2020)

Desa Hambuku Tengah terletak di tepi sungai Nagara yang berjarak kurang lebih 7,5 Km dari ibukota kecamatan (Alabio) dan kira-kira $15 \mathrm{Km}$ dari ibukota kabupaten Hulu Sungai Utara, Amuntai. Desa Hambuku Tengah mempunyai wilayah seluas kurang lebih 1,25 Km atau kira-kira $125 \mathrm{Ha}$.

\section{Tinjauan Lahan Rawa}

Menurut Tim Koordinasi P2NPLRB (Penyusunan Perencanaan Nasional Pengelolaan Lahan Rawa Berkelanjutan) disebut lahan rawa apabila memenuhi 4 (empat) unsur utama berikut, yaitu: (1) jenuh air sampai tergenang secara terus-menerus atau berkala yang menyebabkan suasana anaerobic, (2) topografi landai, datar sampai cekung, (3) sedimen mineral (akibat erosi terbawa aliran sungai) dan atau gambut (akibat tumpukan sisa vegetasi setempat), dan (4) ditumbuhi vegetasi secara alami (WACLIMAD, 2012) dalam (Haryono, muhammad noor, Haris Syahbuddin, 2013)

Dalam Pertemuan Nasional
Pengembangan Pertanian Lahan Rawa
yang diadakan Pusat Penelitian dan
Pengembangan Tanaman Pangan tahun
1992 di Cisarua, Bogor disepakati bahwa
lahan rawa dibagi dalam 2 (dua) tipologi
rawa, yaitu: (1) rawa pasang surut dan (2)
rawa lebak.

\section{Tinjauan Konsep}

1. Konsep Memori

a. Pengertian Memori

Secara etimologi, kata memori berasal dari bahasa inggris yaitu 'memory'. Secara sederhana, memori adalah kemampuan untuk menyimpan informasi sehingga dapat digunakan lagi dimasa yang akan datang. Manusia atau organisme dapat menyimpan informasi yang diterima yaitu melalui semua indera yang akan diubah bentuknya sedemikian rupa sehingga dapat disimpan kedalam otak. Secara singkat memori dapat diartikan sebagai suatu sistem pengolahan informasi. Fungsi Memori terbagi menjadi tiga yaitu, Encoding, Storage, dan Retrieval.(Raharjo, Oko, 2009) dalam (Admin N, 2018)

b. Memori dalam Rancangan Desain Wisata Desa 


\section{PEMBAHASAN}

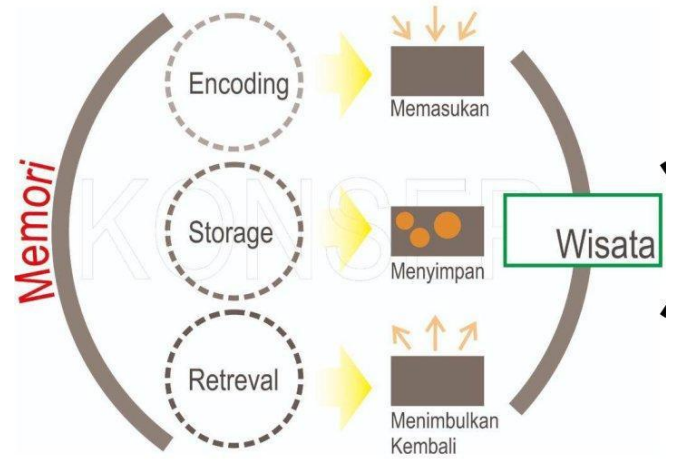

Gambar. 4 Konsep Memori

Sumber : Analisis Pribadi (2020)

Rancangan wisata desa mengambil prinsip dasar dari fungsi memori tersebut, yaitu :

1) Encoding (Memasukkan Informasi) dengan menampilkan simbol-simbol dan bentuk-bentuk sesuai cerita adat dan kebiasaan masa lampau sehingga menjadi informasi kepada wisatawan yang baru mengenal akan adat dan kebiasaan masa lampau di Desa Hambuku Tengah.

2) Storage (Menyimpan) dengan merasakan suasana, melihat dan terlibat langsung dalam atraksi yang disuguhkan maka ingatan akan masa lampau dan kesan akan wisata desa di Desa Hambuku Tengah semakin melekat.

3) Retrieval (Menimbulkan Kembali) adalah kesan yang diberikan menjadi kenangan yang akan dimunculkan kembali melalui kisah para wisatawan sehingga ini juga menjadi oleh-oleh non fisik yang akan dibawa pulang. Keseluruhan atraksi yang disuguhkan akan menimbulkan kembali ingatan bagi wisatawan yang dulu pernah merasakan kebiasaan masa lampau tersebut.

\section{A. Lokasi}

Lokasi rancangan dipilih berdasarkan kriteria yang cocok untuk dibangunnya tempat wisata desa melalui prinsip-prinsip pariwisata, Attraction, Accessibility, Amenity, dan Institution, yaitu :

1. Termasuk dalam wilayah Kalimantan Selatan

2. Berada di pedesaan atau sebuah desa

3. Memiliki kondisi alam yang masih asri dan lingkungan yang berpolusi rendah

4. Sumber daya alam yang dapat dimanfaatkan sebagai objek wisata

5. Memiliki lahan rawa yang subur

6. Masyarakat yang tinggal di lokasi tersebut masih ada yang bisa atau melakukan tradisi masa lampau daerah tersebut

7. Terdapat kesenian lokal, tradisi atau kebiasaan yang terdapat di lokasi

8. Masyarakat yang tinggal di lokasi tersebut tidak primitif atau sudah menyesuaikan diri dengan era sekarang dan bersifat terbuka terhadap orang luar

9. Lokasi sudah terjangkau jaringan telepon dan internet

10. Terdapat instalasi air bersih dan utilitas yang memadai

11. Terdapat instalasi jaringan listrik yang baik

12. Lokasi yang tidak rawan bencana

Berdasarkan kriteria pemilihan lokasi, Desa Hambuku Tengah memenuhi syarat menjadi lokasi yang tepat untuk perencanaan pembangunan wisata desa.

Potensi Desa Hambuku Tengah sebagai lokasi yang dipilih berupa lahan rawa, sungai, telaga, dan juga masyarakatnya. 


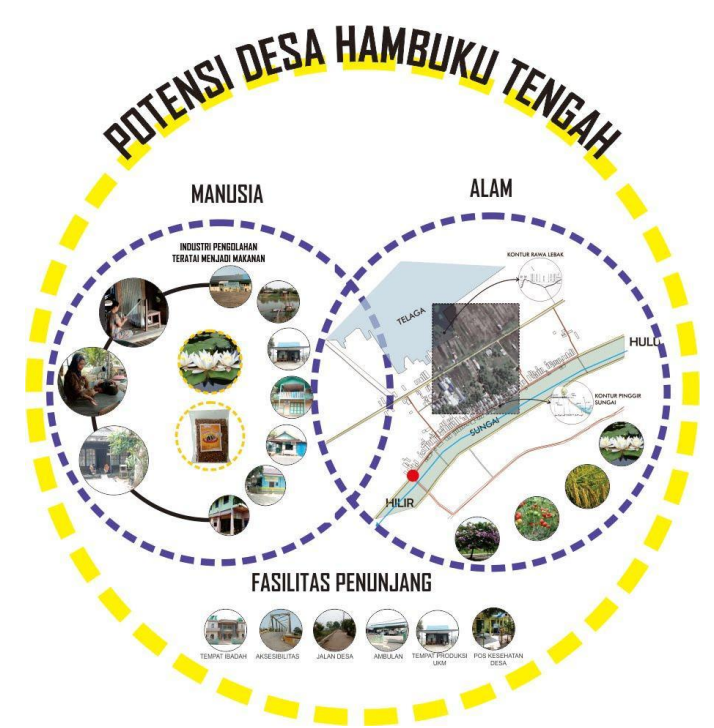

Gambar. 5 Potensi Desa Hambuku Tengah Sumber : Analisis Pribadi (2020)

Potensi lahan rawa memberikan keuntungan pada sektor pertanian di Desa Hambuku tengah, yang mana lahan rawa di sana memiliki kondisi tanah yang subur sehingga pada musim kemarau masyarakat Desa Hambuku Tengah mampu memproduksi sayur dan buah berupa padi, cabe, terong, singkong, gambas, timun suri, dan lain-lain. Sayur dan buah yang diproduksi merupakan tanaman organik karena proses penanamannya tidak menggunakan zat-zat kimia seperti pestisida. Sedangkan pada musim hujan, rawa lebak akan terendam dan dimanfaatkan masyarakat setempat untuk memancing dan memanen talipuk (biji teratai) sebagai bahan pangan khas daerah.

Potensi sungai yang ada, mampu menjadi jalur transportasi air yang menghubungkan antar desa dan menjadi salah satu sumber irigasi untuk mengairi sawah, serta sebagai tempat memancing, sehingga memberikan keuntungan dalam sektor perikanan, pertanian dan kemudahan aksesibilitas.

Telaga yang menjadi potensi dalam sektor perikanan disebabkan, merupakan daerah yang tergenang air cukup dalam sehingga sangat tepat menjadi area menangkap maupun membudidayakan ikan air tawar. Selain potensi-potensi alam yang ada, Desa Hambuku Tengah juga memiliki potensi yang berasal dari kebiasaan dan adat masyarakat setempat, yang mana hal tersebut dapat menambah atraksi sekaligus menjadi ciri khas wisata desa,.

\section{B. Konsep Program}

Proses perancangan meliputi dua tahap, yakni tahap analisis dan tahap sintesis di mana proses penyusunan program adalah tahap analisis, dan proses perancangan adalah tahap sintesis. Tahap inilah yang menjadi metode dalam penyelesaian permasalahan arsitektural.

Metode analisis-sintesis menggunakan pendekatan lokalitas mencakup kedalam unsur lokalitas, yaitu folk, work, place (Dower, 1993) dalam (Sugiman, Hobson, \& Lloyd, 2013). Penggunaan metode tersebut disesuaikan itu sehingga memenuhi syarat wisata.

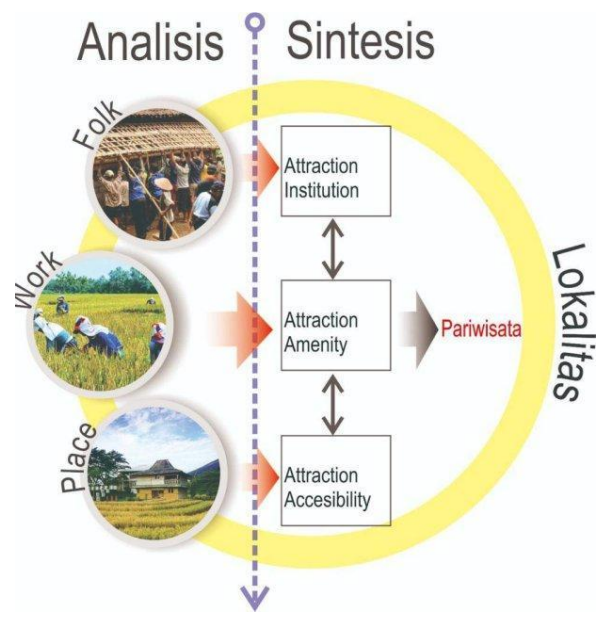

Gambar. 6 Konsep Program Perancangan Sumber : Analisis Pribadi (2020)

Berikut adalah alur program perancangan menggunakan metode analisis-sintesis : 


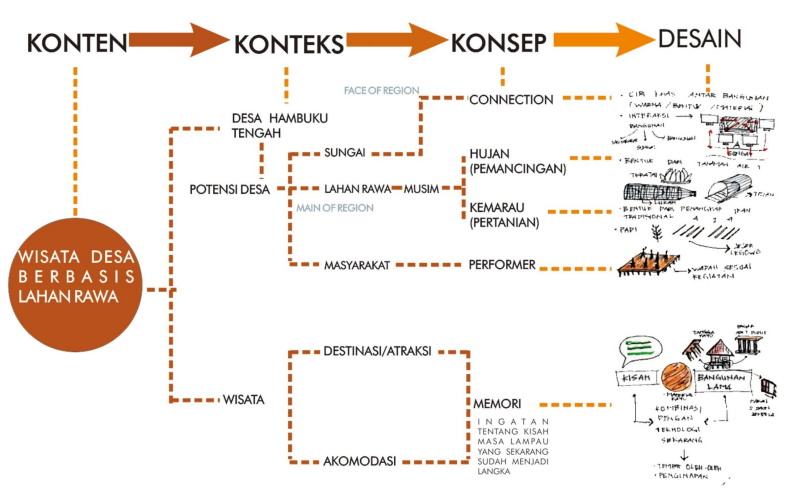

Gambar. 7 Alur Program Perancangan Sumber : Analisis Pribadi (2020)

Proses dari konten sampai konsep adalah tahap analisis sedangkan desain merupakan tahap sintesis. Konten yang berupa wisata desa berbasis lahan rawa yang juga menjadi judul perancangan, konten yang ada mewakili konteks berupa Desa Hambuku Tengah sebagai lokasi rancangan dan wisata sebagai jenis rancangan.

Desa Hambuku tengah memiliki potensi berupa sungai, lahan rawa, dan juga masyarakatnya yang mana itu menjadi konsep program rancangan yang akan dibangun, seperti sungai berkonsep penghubung antara kawasan, lahan rawa berkonsep berdasarkan musimnya, dan masyarakat yang menjadi penampil di wisata desa tersebut.

Konteks wisata memiliki unsur penting yaitu, atraksi atau destinasinya dan juga akomodasi yang akan disuguhkan untuk wisatawan. Perencanaan rancangan wisata ini memiliki konsep memori, bertujuan untuk memberikan kesan dan ingatan terhadap suasana pedesaan yang tidak hanya dirasakan ketika berada di kawasan wisata, tetapi juga setelah meninggalkan kawasan wisata. konsep inilah yang menjadi konsep utama atau tema dalam menata dan merancang bangunan. Konsep-konsep yang ada dipadukan sehingga menjadi acuan desain untuk merancang wisata desa tersebut yang akan diterapkan di setiap bangunan rancangan.

\section{Konsep Rancangan}

\section{Konsep Kawasan}

Kawasan dibagi menjadi empat zona untuk memudahkan perancangan kawasan wisata.

a. Zona pertama, adalah zona penerimaan, yaitu akses masuk dalam kawasan atau bagian depan dari kawasan wisata desa.

b. Zona kedua, adalah zona pelayanan, yaitu wisatawan akan memilih paket wisata yang akan dinikmati

c. Zona Ketiga, adalah zona inti, yaitu zona wisata utama yang mana zona ini wisatawan akan disuguhkan berbagai atraksi.

d. Zona Keempat, adalah zona pengembangan, yaitu zona atraksi tambahan dari zona inti pada kawasan wisata desa.

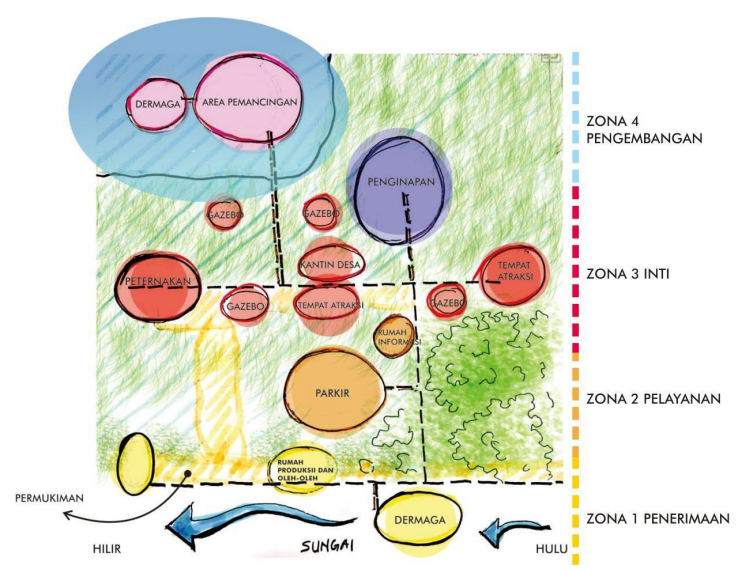

Gambar. 8 Konsep Pembagian Zona Kawasan Sumber : Analisis Pribadi (2020)

\section{Konsep Bangunan}

Bentuk bangunan terinspirasi dari komoditas alam dan buatan yang ada di desa dengan menyesuaikan kondisi lingkungan yang ada, seperti bangunan penginapan yang terinspirasi dari rumah penduduk, dilihat dari bentuk jendela, pintu, dan dan bentuk dasar bangunan. 

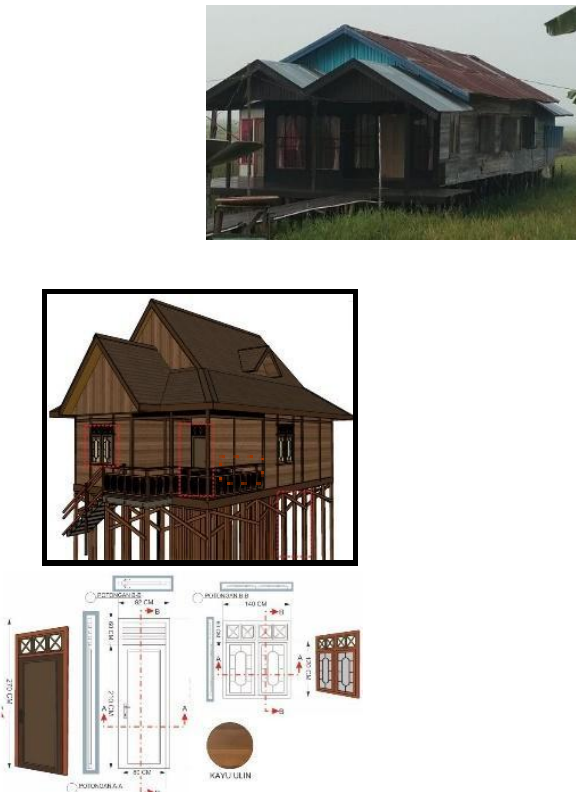

Gambar. 9 Konsep Bangunan Penginapan Sumber : Analisis Pribadi (2020)

Bangunan dibuat panggung karena menyesuaikan kondisi lingkungan lahan rawa.
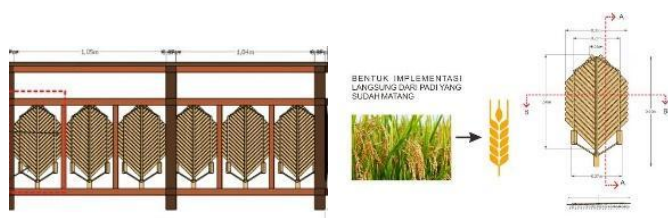

Gambar. 10 Konsep Bentuk Pagar Balkon Sumber : Analisis Pribadi (2020)

Selain itu, tanaman padi sebagai salah satu komoditas utama lahan rawa menjadi inspirasi bentuk yang diterapkan pada pagar balkon bangunan dan signage kawasan.

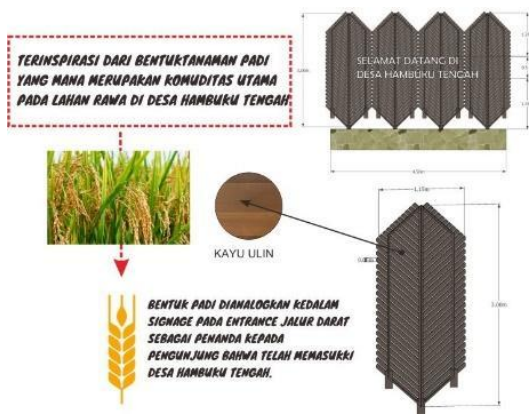

Gambar. 11 Konsep signage
Bentuk padi yang

Keong dan teratai yang menjadi komoditas lahan rawa juga menjadi inspirasi bentuk bangunan.
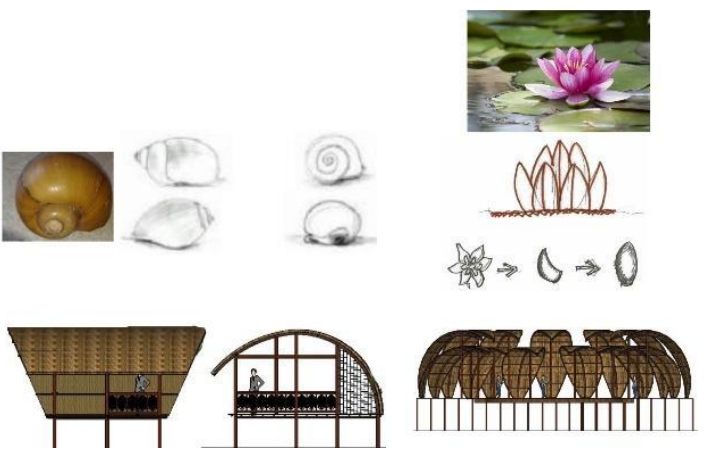

Gambar. 12 Konsep Bangunan Rancangan Sumber : Analisis Pribadi (2020)

3. Konsep Material, Warna dan Konstruksi

Material bangunan yang digunakan menggunakan bahan bambu dan kayu sehingga memberikan kesan pedesaan dan selaras dengan bangunan yang sudah ada. Material bambu digunakan di beberapa elemen rancangan seperti pada lampu jalan dan bangunan, beberapa ornamen bangunan, dan penanda jalan.

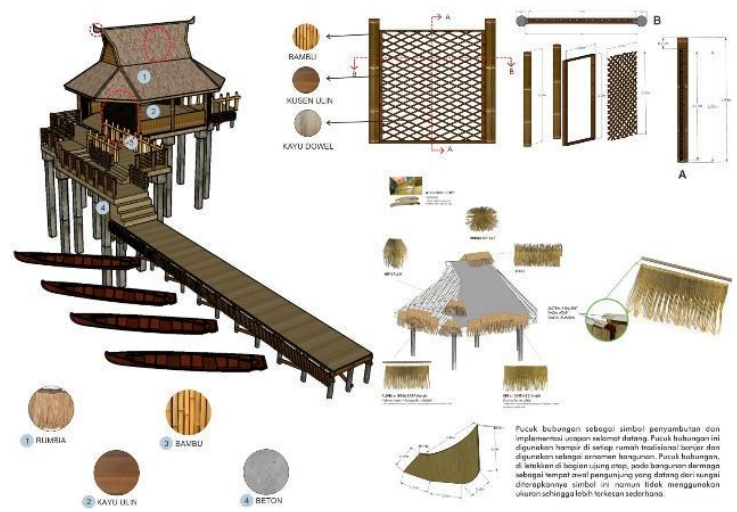

Gambar. 13 Konsep Material Bangunan Sumber : Analisis Pribadi (2020) 
Kayu ulin menjadi material utama yang digunakan karena memiliki daya tahan yang kuat dan sangat cocok digunakan di lahan rawa. Selain kayu ulin ada beberapa material kayu yang dikombinasikan seperti kayu meranti dan kayu sonokeling sebagai ornamen dan kusen jendela.

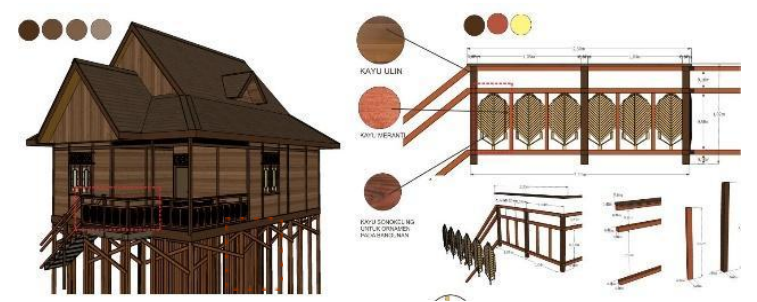

Gambar. 14 Konsep Material dan warna Bangunan

Sumber : Analisis Pribadi (2020)

Warna coklat dari kayu memberikan kesan alami karena didapat langsung dari alam.

Pondasi yang digunakan sebagai konstruksi bangunan berupa pondasi tiang pancang kayu ulin. Pondasi jenis ini merupakan pondasi yang paling cocok digunakan di lahan rawa karena memiliki ketahanan yang kokoh dalam menopang bangunan di lahan tersebut.

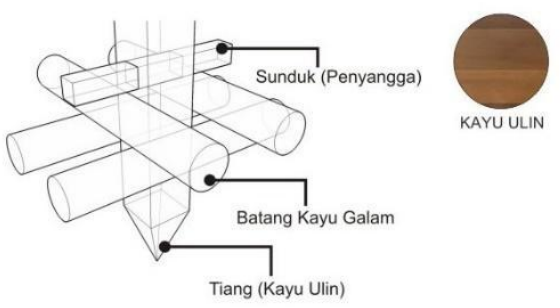

Gambar. 15 Konsep Pondasi Bangunan Sumber :

http://1.bp.blogspot.com/ xnR5i2 A514/Sw1UVQ 4Qoll/AAAAAAAAACo/G432xYd2FJM/s1600/d.jp $g$

\section{HASIL}

Hasil analisis dari masalah yang ada menghasilkan suatu bentuk rancangan berdasarkan konsep memori dengan mengandalkan potensi Desa Hambuku Tengah. Rancangan pada setiap zona dibuat mewakili potensi kawasan yang ada.

\section{Isometrik kawasan}

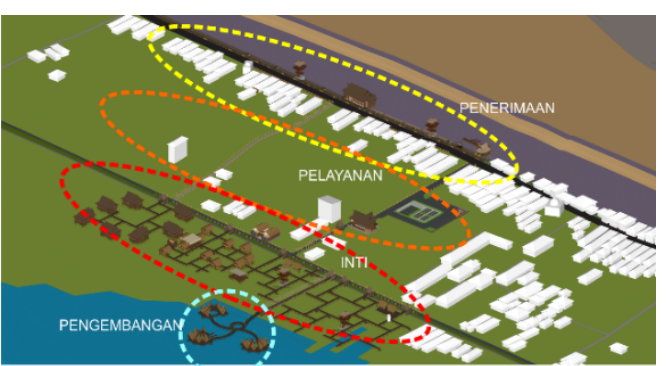

Gambar. 16 Isometrik Kawasan Sumber : Analisis Pribadi (2020)

\section{Potongan kawasan}
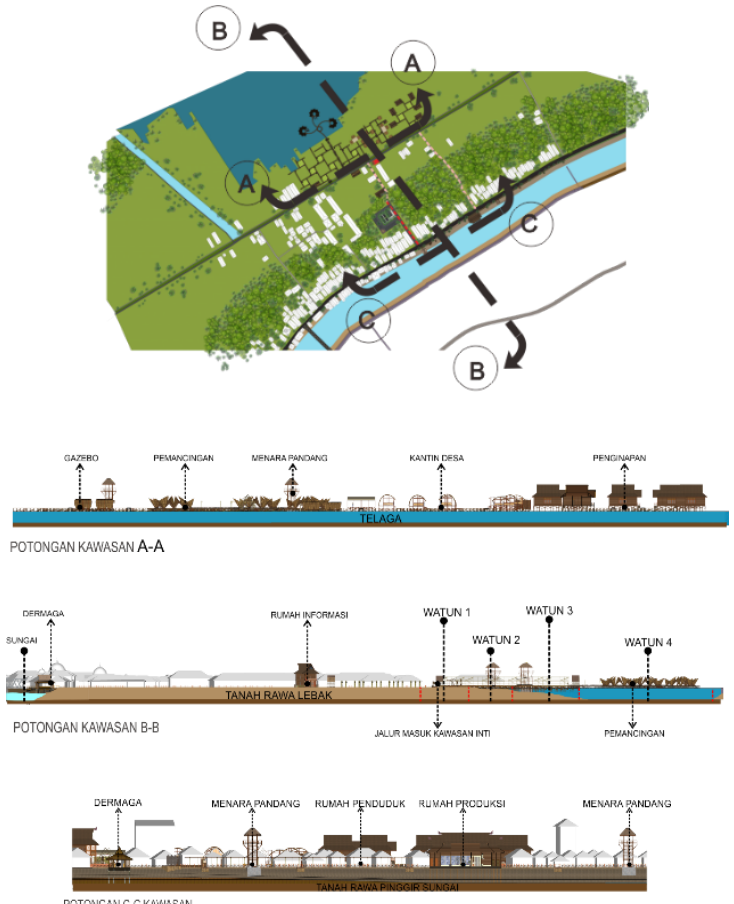

Gambar. 17 Potongan Kawasan Sumber : Analisis Pribadi (2020) 


\section{Tampak kawasan}


Gambar. 18 Tampak Dermaga

Sumber : Analisis Pribadi (2020)
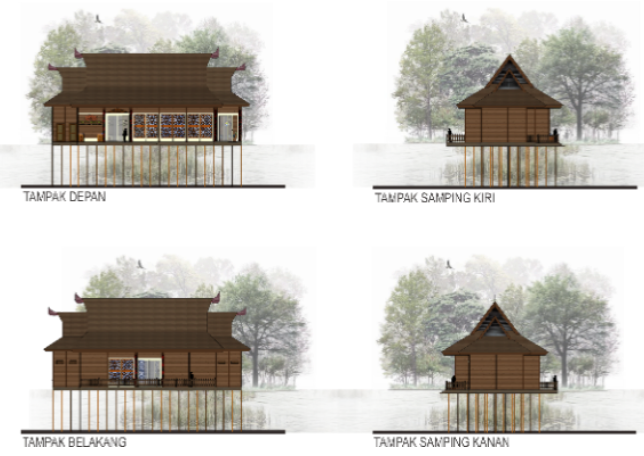

Gambar. 19 Tampak Rumah Produksi Sumber : Analisis Pribadi (2020)
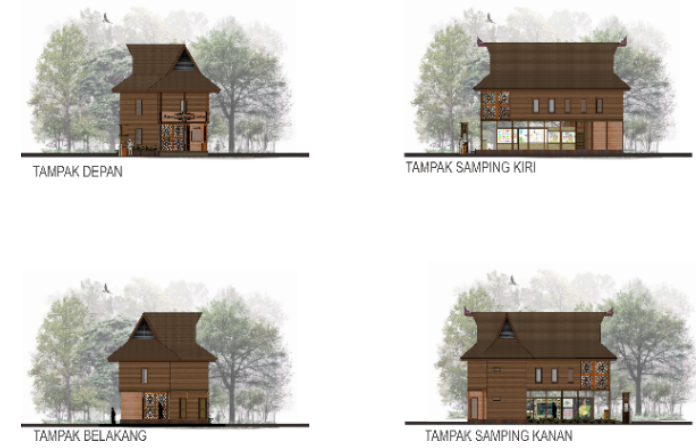

Gambar. 20 Tampak Rumah Informasi Sumber : Analisis Pribadi (2020)
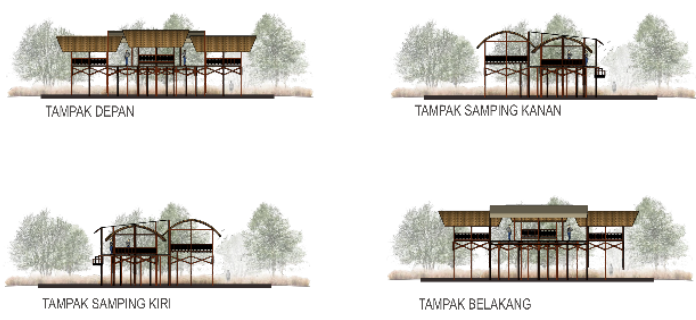

Gambar. 21 Tampak Tempat Atraksi Sumber : Analisis Pribadi (2020)
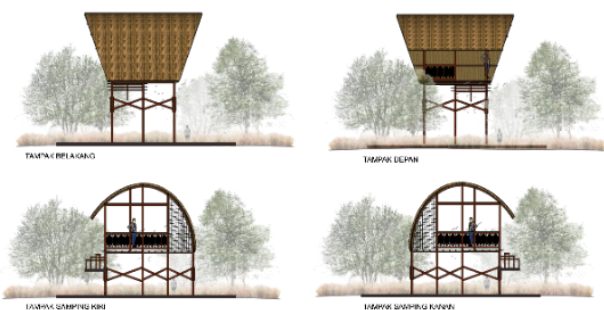

Gambar. 22 Tampak Gazebo Sumber : Analisis Pribadi (2020)

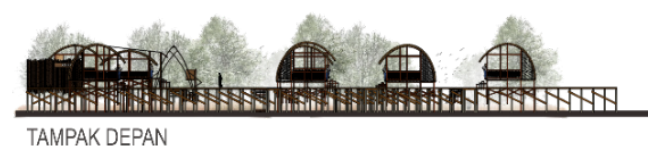
TAMPAK DEPAN
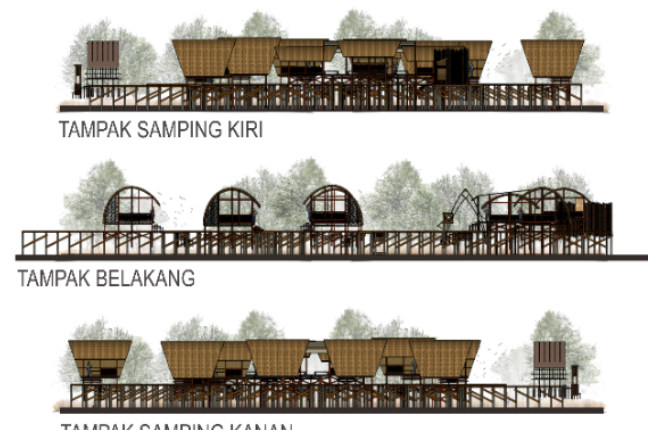

TAMPAK SAMPING KANAN

Gambar. 23 Tampak Kantin Desa Sumber : Analisis Pribadi (2020)


Gambar. 24 Tampak Penginapan

Sumber : Analisis Pribadi (2020) 


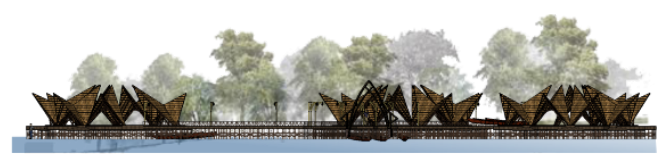

TAMPAK DEPAN



TAMPAK BELAKANG

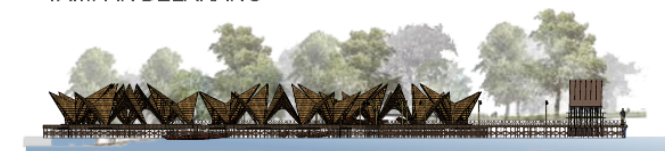

TAMPAK SAMPING KANAN



TAMPAK SAMPING KANAN

Gambar. 25 Tapak Pemancingan

Sumber : Analisis Pribadi (2020)

\section{Perspektif Eksterior Kawasan}
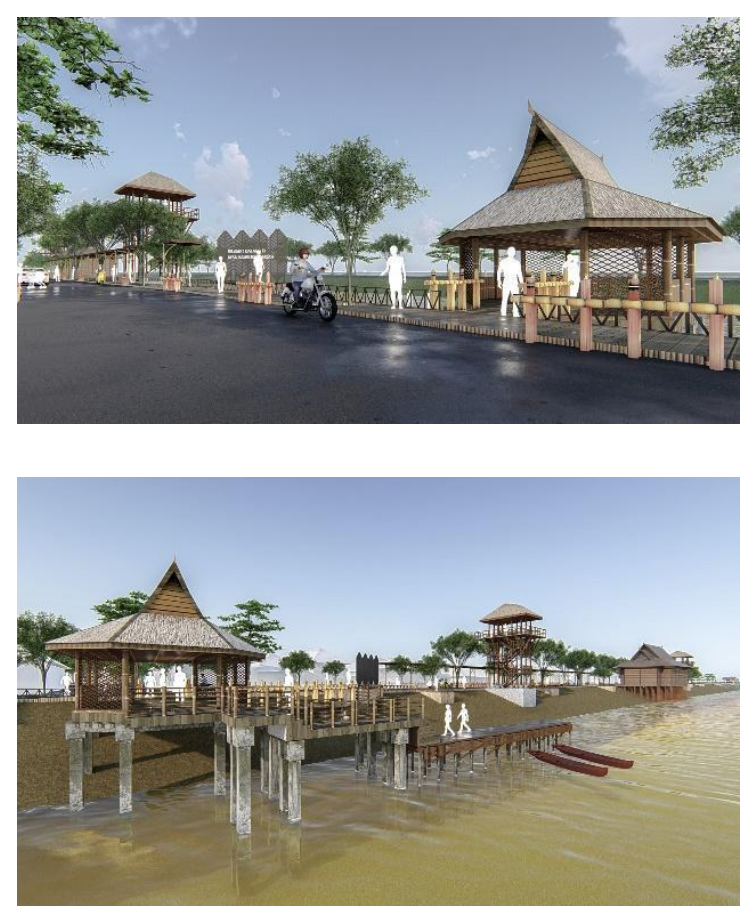
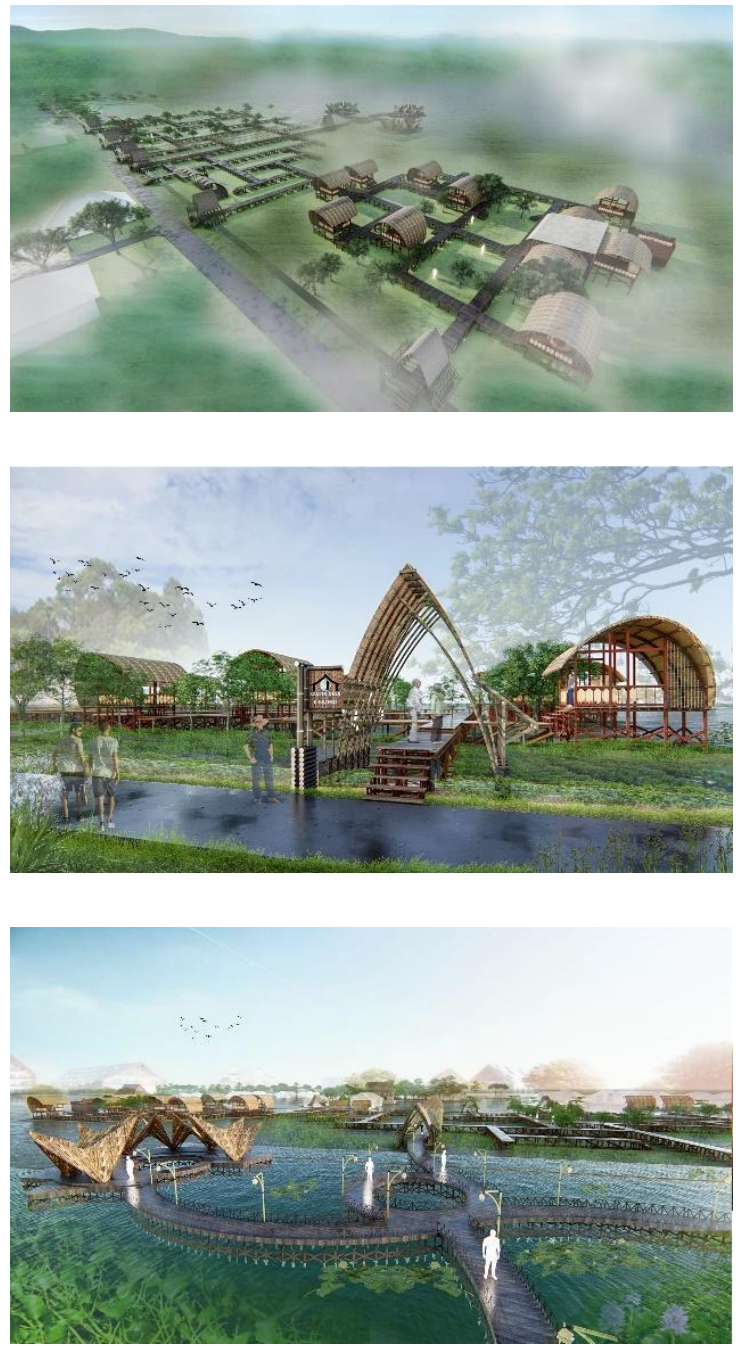

Gambar. 26 Perspektif Eksterior Kawasan Sumber : Analisis Pribadi (2020)

\section{KESIMPULAN}

Wisata Desa Berbasis Lahan Rawa di Desa Hambuku Tengah merupakan wadah rekreasi yang mengandalkan potensi Desa Hambuku Tengah. Potensi yang ada berupa potensi alam dan masyarakat setempat. Berlokasi di Desa Hambuku Tengah Kecamatan Sungai Pandan Kabupaten Hulu Sungai Utara Provinsi Kalimantan Selatan. Melalui wisata desa pemanfaatan dan pelestarian lahan rawa menjadi solusi yang tepat sekaligus berdampak terhadap perekonomian, pelestarian alam dan budaya lokal, serta memberikan edukasi terhadap 
masyarakat tentang lahan rawa dan memberikan pengalaman menjalani hidup di desa.

Rancangan wisata desa berbasis lahan rawa menerapkan metode analisis sintesis dengan konsep memori. Potensi desa, baik berupa alam dan masyarakatnya dianalisis sehingga dapat menjadi daya tarik wisatawan dan dapat memecahkan masalah, hasil analisis disintesiskan sesuai dengan unsur-unsur pariwisata, yang kemudian akan membentuk rancangan. Perencanaan rancangan wisata desa menggunakan konsep memori dilakukan sebagai daya tarik dan kekhasan wisata ini. Konsep memori dimaksudkan untuk memberikan ingatan baru ataupun mengembalikan ingatan terhadap suasana dan kesan masa lampau di pedesaan sehingga konsep ini juga akan mengangkat unsur lokalitas. Konsep wisata desa ini secara langsung menjadi ciri khas dan keunikan tersendiri karena kebiasaan, adat, budaya serta potensi yang ada di Desa Hambuku Tengah tidak terdapat di wilayah lainnya.

\section{DAFTAR PUSTAKA}

\section{Referensi Buku dan Jurnal}

Alim Irhamna, S. (2018). Dampak Pengembangan Pariwisata Terhadap Perekonomian Masyarakat Sekitar Objek Wisata di Dieng Kabupaten Wonosobo. Economics Development Analysis Journal, 6(3), 320-327. https://doi.org/10.15294/edaj.v6i3.22277

BPS HSU. (2018). kecamatan Sungai Pandan dalam Angka. Amuntai: BPS HSU.

Djauzi, S. (1997). Peluang di Bidang Pariwisata. Jakarta: Mutiara Sumber Widya.

Dower, M. (1993). Local Distinctiveness: An Idea for Europe, in S. Clifford \& A. King (eds.), Local Distinctiveness: Place, Particularity and Identity.

Fandeli, C. (2001). Dasar-Dasar Manajemen Kepariwisataan Alam. Yogyakarta: Liberty.

Haryono, muhammad noor, Haris Syahbuddin,
M. S. (2013). Lahan Rawa Penelitian dan Pengembangan. Jakarta: Badan Penelitain dan Pengembangan Pertanian.

Raharjo, Oko, B. (2009). Jurnal Memori.

Sugiman, T., Hobson, H., \& Lloyd, F. (2013). Tinjauan Penerapan Lokalitas pada Bangunan Tinggi, 35-39.

Suyitno. (2001). Perencanaan Wisata. Yogyakarta: Kanisius.

Thira, I. J., Mayangky, N. A., Kholifah, D. N., Balla, I., \& Gata, W. (2019). Peramalan Data Kunjungan Wisatawan Mancanegara ke Indonesia menggunakan Fuzzy Time Series. Jurnal Edukasi Dan Penelitian Informatika (JEPIN), 5(1), 18. https://doi.org/10.26418/jp.v5i1.31074

WACLIMAD. (2012). Water Management for Climate Change Mitigation and Adaptive Management Development (WACLIMAD) in Low Land. Jakarta.

Zakaria, F., \& Suprihardjo, D. (2014). Konsep Pengembangan Kawasan Desa Wisata di Desa Bandungan Kecamatan Pakong Kabupaten Pamekasan. Teknik Pomits, 3(2), C245-C249. https://doi.org/2337-3520

\section{Website}

Admin N. (2018). Pengertian Memori Manusia Lengkap Fungsi, Jenis, Teori, Proses dan Usaha Meningkatkan Kemampuan Memori. Retrieved from http://www.markijar.com/2018/11/pengertia n-memori-manusia-lengkap.html

Badan Pusat Statistik Indonesia. (2020). No Title. Retrieved January 31, 2020, from https://www.bps.go.id/subject/16/pariwisat a.html 